International Journal of Educational Development, Vol.49, 2016, pp.291-299. DOI:

10.1016/j.ijedudev.2016.04.003

\title{
The Internal Dynamics of Privatised Public Education: Fee-charging Supplementary Tutoring Provided by Teachers in Cambodia
}

\author{
Mark Bray, Magda Nutsa Kobakhidze, Junyan Liu \& Wei Zhang \\ Comparative Education Research Centre, Faculty of Education, The University of Hong Kong \\ mbray@hku.hk; nkobakhidze@gmail.com; liujy0211@hotmail.com; weizh@hku.hk
}

\begin{abstract}
Much literature is available on private schools that operate alongside public schools, and on public schools that are encouraged to operate more like businesses in order to become more efficient and client-oriented. This paper, by contrast, focuses on privatisation by default behind a façade of fee-free education. It concerns supplementary private tutoring provided by government-employed teachers, in many cases to their own students in large classes and on the school premises. Drawing on questionnaire and interview data from secondary school students and teachers in one province of Cambodia, the paper examines interlinked factors that contribute to this process. These factors include low teachers' salaries, lack of instructional time, large classes, and the possibility of different teacher-student relationships in supplementary lessons. The paper is contextualised within the wider literatures on privatisation and shadow education.
\end{abstract}

Keywords: Cambodia; shadow education; privatisation; private supplementary tutoring

The literature on marketisation and commodification of education has greatly expanded in recent years (see e.g. Ball 2012; Burch 2009; Macpherson et al. 2014). Much of it focuses on the development of private schools alongside public ones (e.g. Pugh et al. 2006; Woodhead et al. 2013), but parts, like the present paper, focus on privatisation within public education (e.g. Ball \& Youdell 2008; Silova et al. 2006). Such privatisation may result from deliberate policy but can also occur by default.

Cambodia's education system has long had much internal privatisation behind a façade of fee-free public provision (see e.g. Bray 1999; Bray \& Bunly 2005; Nguon 2012; Sophonnara 1994), and reports by international agencies and Non-Governmental Organisations (NGOs) have expressed concern about exclusion of low-income families (e.g. Asian Development Bank 1996; NGO Education Partnership 2007; UNDP 2014). 
Yet despite over two decades of concern, the issues have remained entrenched because the basic drivers of this privatisation have not sufficiently changed.

This paper adds to understanding by reporting new data and insights on one component of privatisation, namely supplementary tutoring provided by public school teachers on a fee-charging basis mostly to students in their own schools and commonly to students in their own classes. The data were collected from a sample of urban, semi-urban, rural and remote schools in one province of Cambodia, using both quantitative and qualitative methods. The paper analyses the forces that sustain and contribute to the privatisation within public education, and remarks on the policy implications. Patterns in Cambodia are not unique, and indeed exist in many countries (see e.g. Bray 2009; Jokić 2013; Kobakhidze 2014; Majumdar 2014). However, they are particularly interesting because they are extreme and therefore expose forces that may be less easily detected elsewhere.

This paper commences with the international literature and conceptual framework. It then turns to the Cambodian context and to the methods through which the data were collected. Subsequent sections indicate the scale and nature of private supplementary tutoring, and the factors that underpin it. Analysis of these factors leads to remarks about the levers for policy makers who might decide to intervene.

\section{International Literature and Conceptual Framework}

This paper is especially concerned with the behaviour of teachers in public schools, but also with the behaviour of students and, by extension, their families. Teachers' identities are partly determined by recruitment and retention policies; and their behaviours are shaped by the environments in which they work. Such factors have been identified by sociologists in under the heading of sociological institutionalism (see e.g. Hall \& Taylor 1996; Jepperson 2002). Salaries are a core factor in teacher recruitment and retention, and in Cambodia are low. Tandon and Fukao (2015, p.19) stated that "[t]he wages of a typical married Cambodian teacher with two children are below the poverty line", adding (p.24) that teachers earn less than comparable professionals. This problem was longstanding (see e.g. Benveniste et al. 2008, p.52; Chhinh \& Dy 2009, p.128; Engel 2011, p.15; Naren \& Collins 2004, p.4). Patterns in Cambodia resemble those elsewhere (e.g. Liu \& Onwuegbuzie 2014; Mkumbo 2012) in which education systems with low salaries are unable to attract the best applicants; and when salaries are very low, teachers have to supplement their incomes through other means. Private tutoring is among the common means to supplement salaries both in Cambodia and elsewhere (Brehm et al. 2012; Jayachandran 2014; Silova et al. 2006). Such tutoring is commonly called shadow education on the grounds that much of it mimics the content of regular schooling (Aurini et al. 2013; Bray 2009; Jokić 2013; Majumdar 2014).

Intermeshing with the teachers are the students and their families. Insofar as students and their families see education as an investment in a competitive environment, anxieties particularly arise around points in education systems at which students are streamed or pushed out. In all education systems, external examinations are a major factor (see e.g. Chang 2013; Safarzyńska 2011; Zeng 1999). If private supplementary tutoring helps students to pass these examinations, then it can be a good household investment. 
Yet career progression in education systems is not determined only by external examinations. Other important determinants include internal examinations, usually set by teachers with or without some level of school monitoring and moderation. Brehm (2015, p.62) has described decision-making by a low-income parent in Cambodia who entered a debt relationship with her children's teacher because of "her desire for a future in which her child would earn a high salary”. This parent clearly saw private tutoring as an investment, though the extent to which it was a reliable investment may have been uncertain. Also important in the decisionmaking by students and their families are elements of classroom climate shaped by peers and teachers (Jheng 2015). Peer pressure may play a particularly strong role when the majority of students receive private tutoring; and teachers may have different attitudes to students who do or do not receive tutoring.

Teachers who provide tutoring do not simply respond to demand: they can also create or stimulate it. In Cambodia, Dawson (2009) referred to the 'tricks of the teacher' to secure demand for their supplementary classes by deliberately slowing down in regular lessons and/or withholding key components. Dawson (p.65) quoted one teacher who had stated:

That's the way we force the students to study in private tutoring. The teacher says the new math formulas are only introduced in private tutoring.

In more benign settings teachers do not operate in ways that are arguably corrupt; but they may still encourage tutoring - perhaps inadvertently - by favouring the students who receive the tutoring over ones who do not.

Other factors which shape shadow education demand and supply concern the structure and content of education systems. Structure includes class size and duration of the learning day. When school classes are large, students and their families may seek (and teachers may recommend) supplementary lessons in smaller classes in order to gain more individual attention (see e.g. Ireson \& Rushforth 2014); and when school days are shortened, for example by the operation of double-shift systems in which one group of students attends school in the morning and another group attends in the afternoon, then students and families may seek (and again teachers may recommend) extra lessons to make up for the shortfall (see e.g. Tedla 2003, p.105). These are factors in Cambodia, where urban classes in particular are commonly large, and where the school day may be short in part because of double shifts. In such contexts, the official curriculum may be overloaded for the capacity of the system.

Going beyond these factors, this paper considers other variables. One concerns teacher absenteeism, which is a problem in many countries (Abadzi 2007; Lee et al. 2015; Rogers \& Vegas 2009) including Cambodia (Benveniste et al. 2008, pp.66-71; Sopha et al. 2015, pp.29-43), and is related to both low salaries and inadequate mechanisms for supervision and accountability. When teachers are absent, their students suffer; and sometimes teachers are absent from their regular duties because they devote time and energy to their market-driven supplementary tutoring. Another variable concerns the pedagogies of private tutoring which may differ even when lessons are delivered by the same teachers to the same students (Brehm et al. 2012, p.24; Brehm 2015, p.67). 
Also pertinent is literature on privatisation in education. Ball and Youdell (2008) identified two types of privatisation. One was called 'endogenous' (p.14) and involves "the importing of ideas, techniques and practices from the private sector in order to make the public sector more like businesses and more businesslike" through increased parental choice, budget devolution, competition between schools and other mechanisms. The other type was called 'exogenous' (p.14) through "the opening up of public education services to private sector participation on a for-profit basis and using the private sector to design, manage or deliver aspects of public education". The patterns described here could perhaps be called endogenous but are very different from the sorts of business-oriented model that Ball and Youdell had in mind.

Pulling these threads together, Figure 1 shows the principal components addressed by this paper. While it does not show all possible components in interrelationships, it goes further than previous literature and explores components that are relevant to other countries as well as to Cambodia. The concluding section of the paper presents another diagram which to show how patterns may be interpreted within an under-funded education system. Most of the existing literature about neoliberalism is concerned with macro-level forces (e.g. Apple 2006; Ball \& Youdell 2008; Ward 2013). This paper is chiefly concerned with ways that the wider forces play out at the school level.

Figure 1: Components Underlying and Impacting on Private Supplementary Tutoring Demand and Supply

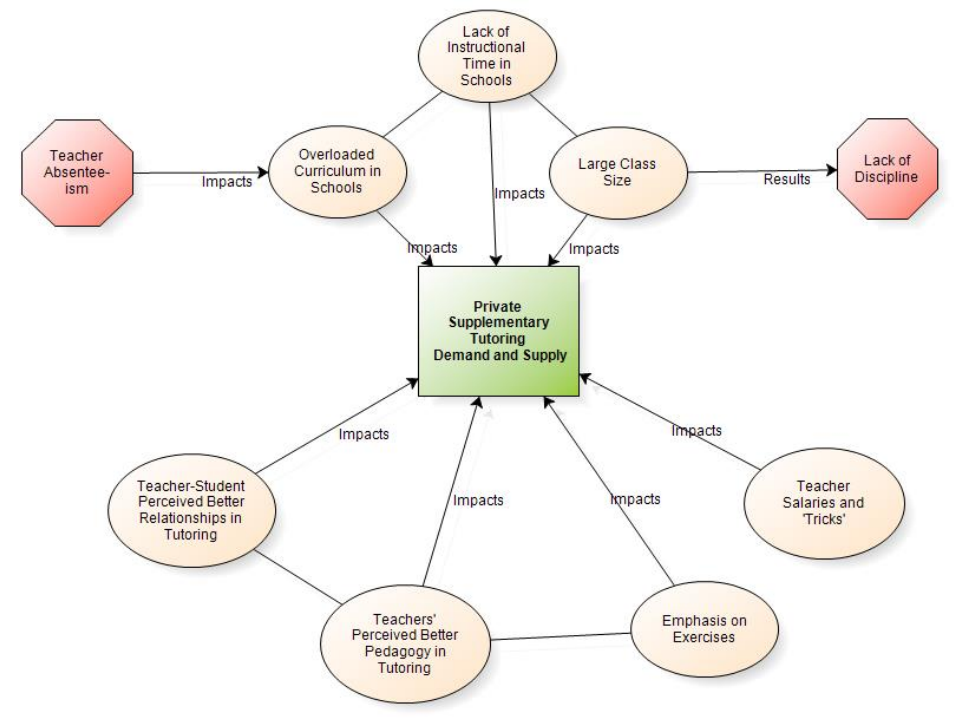

\section{The Cambodian Context}

Following the devastation of the 1975-79 Pol Pot regime and its aftermath (Chandler 2008, pp.255-276), Cambodia has achieved remarkable economic growth. Madhur and Rethy $(2015$, p.1) describe the country as "on the verge of graduating to lower-middle-income status with a per capita income of about USD1000", adding that that level was reached by Vietnam in 2010 and by Laos in 2011. Three quarters of the population 
are rural residents, and agriculture is the mainstay of the economy. Membership of the Association of Southeast Asian Nations (ASEAN) has expanded regional flows of capital and labour.

Cambodia has 24 provinces, among which the data on which this paper reports were drawn from Siem Reap. This province has approximately 1.0 million people, representing 6.7 per cent of the national population (Cambodia, Ministry of Planning 2013). Siem Reap town is Cambodia's greatest tourist hub, neighbouring Angkor Wat; but incomes beyond the town are below the national average (Asian Development Bank 2014, p.27).

Cambodia's education system has a $6+3+3$ structure, i.e. six years of primary, three years of lower secondary, and three years of upper secondary schooling. Primary school enrolment rates exceed $90 \%$, but are much lower at the secondary level. Nationally, in 2014/15 respective gross enrolment rates for lower and upper secondary schooling were $53.3 \%$ and $24.2 \%$ (Cambodia, Ministry of Education, Youth \& Sport [MoEYS] 2015, p.41). The figures for Siem Reap Province were close to the national average, i.e. respective gross enrolment rates for lower and upper secondary of $52.2 \%$ and $22.9 \%$.

Gender issues are also pertinent to this paper. While enrolment rates by gender were almost equally balanced at the primary level, in both Siem Reap and the country as a whole girls were more numerous than boys in secondary education. In Siem Riep the recorded lower secondary gross enrolment rate for boys was $46.7 \%$ compared with $58.0 \%$ for girls; and respective figures for upper secondary were $20.5 \%$ and $25.4 \%$ (Cambodia, MoEYS 2015, pp.41-42). These statistics reflected high drop-out rates among boys, often to seek employment including as labourers in neighbouring Thailand facilitated by ASEAN membership. Concerning teachers, nationally $42.6 \%$ of lower secondary and $33.1 \%$ of upper secondary teachers in $2014 / 15$ were female (Cambodia, MoEYS 2015, p.35), and statistics for Siem Reap were close to the national average.

\section{Methodology}

The data reported in this article were collected by a Cambodian NGO in Siem Reap called This Life Cambodia (TLC) in partnership with an external team from the University of Hong Kong (Bray et al. 2015). The researchers wished to secure sufficient depth in their analysis while identifying variations within the province. They therefore selected six schools for analysis: three lower secondary schools serving Grades 7-9, and three high schools serving Grades 7-12. Three schools were urban or semi-urban, and three were rural or remote. The NGO and external team together selected an initial sample of schools, following which the NGO sought approval from the provincial government to conduct the research. The final list reflected the NGO's negotiation with the schools themselves. The researchers sought illustrative examples from across a range of school types and locations rather than statistical representativeness.

Within the schools, the research focused on students in Grades 9 (all six schools) and 12 (the three high schools) on the grounds that these are transition points in the education system and thus of particular importance. Grade 9 has a national examination that marks the end of lower secondary schooling, following which students either proceed to Grade 10 or leave the system. Grade 12 is the terminal year of schooling, 
again marked by a national examination, following which students either proceed to post-secondary studies or join the labour force.

The research had both quantitative and qualitative components. In an initial visit to each school the team explained to teachers and students in the selected grades the purpose of the research. The team then gave the students a summary for them to take to their parents and obtain parental consent. Subsequently the team returned to each school and obtained from the students and teachers their own consent to participate. At the time of distribution of questionnaires to students and teachers, a further invitation was issued to participate in interviews if selected. This paper draws on questionnaire responses from 1,274 students (662 in Grade 9 and 612 in Grade 12), and 72 teachers. It also draws on 48 student interviews and 24 teacher interviews.

Concerning interviews, the research design envisaged a balanced sample in each grade comprising (i) male students with tutoring, (ii) male students without tutoring, (iii) female students with tutoring, and (iv) female students without tutoring. However, some students who had initially agreed to join the interviews subsequently declined and had to be replaced. Also, it proved difficult in some schools to find willing interviewees who were not receiving tutoring. The final balance, partly reflecting the greater proportions of girls in the classes and also the greater willingness of girls to be interviewed - perhaps because they tended to be higher performers - had 31 females but only 17 males. It also had 39 students receiving tutoring compared with only nine who were not. Nevertheless, these balances did to some extent match the broad picture shown by the quantitative data. The teacher interviews secured gender equality: among the 24 interviewees, 12 $(50.0 \%)$ were female and $12(50.0 \%)$ were male. This compared with the average of $46.6 \%$ females among secondary school teachers in the province as a whole.

Once the data had been collected, they were analysed using SPSS and NVivo software. During the analysis the research team became aware of needs for further contextual information at the institutional level relating to timetabling, teacher deployment and other school-level policies. These details were sought from the schools and were added to the analysis.

\section{Scale, Providers and Subjects for Private Tutoring}

The questionnaire responses provided data on the scale of private tutoring and on the subjects in which it was most popular. Among the sampled students, $81.9 \%$ stated that they received private tutoring, with rates in Grade 12 higher than Grade 9 (Table 1). Differences between genders were small, though with a slightly higher rate among females.

Table 1: The Scale of Private Tutoring

\begin{tabular}{|c|c|c|}
\hline & & Proportions receiving private tutoring (\%) \\
\hline \multicolumn{2}{|c|}{ All students } & 81.9 \\
\hline \multirow{2}{*}{ Grade } & Grade 9 & 74.7 \\
\hline & Grade 12 & 89.8 \\
\hline \multirow{2}{*}{ Gender } & Male & 80.9 \\
\hline & Female & 82.8 \\
\hline Location & Urban & 83.5 \\
\hline
\end{tabular}


Table 1 also shows that greater proportions of urban students received tutoring compare with counterparts in other locations. This was in line with patterns in other countries (see e.g. Bray \& Lykins 2012, p.12), but the gap was modest. One reason for the modesty of this gap was that most tutoring was provided by teachers rather than by companies which tend to congregate in urban areas to secure density of population. The question about identities of the tutors, following adjustment of the questionnaire, was only asked in three of the six schools (one semi-urban, one rural and one remote); but among the responding students in those schools receiving tutoring, $57.7 \%$ indicated that they did so from their own teachers and $40.9 \%$ from other teachers in their schools. Only $1.2 \%$ indicated that they received tutoring from a teacher in a different school, $0.6 \%$ from a university student or other self-employed person, and none from a company. Interviews with both students and teachers indicated that most tutoring was provided in the schools already attended by those students and teachers, but occasionally it was held in teachers' houses or other locations such as in the offices of NGOs.

Most students who received tutoring did so in several subjects. Nearly half received tutoring in three to five subjects, and $1.7 \%$ of students received it in over six subjects (Table 2). Not only did more Grade 12 students receive tutoring, they also did so in more subjects: $45.3 \%$ of them received tutoring in over five subjects while that proportion for Grade 9 students was only 8.1\%. Mathematics, Chemistry, Khmer (language and literature), Physics, Biology, and English were the most popular subjects for tutoring.

Table 2: Subjects of Private Tutoring

\begin{tabular}{|l|r|r|l|c|c|}
\hline Number of subjects & \multicolumn{1}{|c|}{ No. } & \% & Subjects & No. & \%* \\
\hline Zero (no tutoring) & 230 & 18.1 & Mathematics & 825 & 79.0 \\
\hline One & 171 & 13.4 & Chemistry & 718 & 68.8 \\
\hline Two & 129 & 10.1 & Khmer & 627 & 60.1 \\
\hline Three & 215 & 16.9 & Physics & 623 & 59.7 \\
\hline Four & 197 & 15.5 & Biology & 461 & 44.2 \\
\hline Five & 218 & 17.1 & English & 296 & 28.4 \\
\hline Six & 91 & 7.1 & Earth and Environmental Studies & 47 & 4.5 \\
\hline More than six & 22 & 1.7 & Geography & 35 & 3.4 \\
\hline Missing & 1 & 0.1 & History & 28 & 2.7 \\
\hline \multirow{2}{*}{ Sampled students } & \multirow{2}{*}{1,274} & \multirow{2}{*}{100.0} & Morality/Philosophy & 15 & 1.4 \\
\cline { 4 - 6 } & & & Other & & 0.2 \\
\hline
\end{tabular}

* Expressed as \% of students receiving tutoring, i.e. excluding ones that did not.

\section{Costs and Benefits}

Some students reported that they paid on a per-lesson basis, while others paid on a monthly basis. Common rates were 500 riels (US\$0.13) per lesson or 10,000 riels (US\$2.50) per month per subject, with rates higher in 
the urban than rural areas. For example, one rural student reported payment of just 100 riels (US\$0.025) per lesson.

The students' questionnaire responses on expenditures varied considerably but averaged at 50,000 riels (US\$12.50) per month. Among the students who responded to the question, $64.9 \%$ agreed and $19.3 \%$ strongly agreed that expenditure on private tutoring was a financial burden. Only $15.8 \%$ of respondents felt that private tutoring was not a financial burden. Two thirds of responding students indicated that standardized fees were charged, while one third indicated that teachers charged differential fees according to students' ability to pay and in some cases provided free tutoring. The same question was asked to the teachers, among whom $43.9 \%$ of those providing tutoring said that they charged the same fee to everybody and the remainder said that they charged different fees according to affordability and for some students provided free tutoring.

Teachers were also asked about the significance of tutoring to their incomes. Reported monthly incomes from tutoring averaged 596,000 riels (US\$166), which meant that these teachers were in effect earning almost as much from private tutoring as from their official salaries (averaging 633,000 riels). However, some teachers chose not to provide tutoring because other ways to supplement their incomes were more remunerative.

Concerning the students' reasons for seeking tutoring, Table 3 indicates the importance of the national examination, especially for Grade 12 students. As noted above, such motivation is common in many countries. More distinctive to Cambodia, despite the fact that the private classes are given by regular teachers, is the demand for private classes to secure exposure to different pedagogical methods. More light was shed on this matter by the interviews. Students commonly indicated that tutoring provided better opportunities to practise exercises. During regular lessons, they felt, teachers mainly explained content and put less emphasis on exercises. A typical illustration was the statement of a Grade 12 student:

I feel that for biology, we don't study the exercises in government [regular] school. We have fewer exercises, so if we don't attend private tutoring we will not understand at all. I won't know how to solve the problem when I am doing the exam.

Many interviewees felt that lessons moved rapidly in regular classes. Teachers, they said, rushed to cover the curriculum but, in the words of one student "in the private tutoring class [the teacher] explains each point clearly and we can ask if we are unclear".

Table 3: Students’ Declared Reasons for Receiving Private Tutoring

\begin{tabular}{|l|c|c|c|c|}
\hline \multirow{2}{*}{ Reasons } & \multicolumn{2}{c|}{ Grade 9 } & \multicolumn{2}{c|}{ Grade 12 } \\
\cline { 2 - 5 } & Percentage* & Importance $\dagger$ & Percentage* & Importance $\dagger$ \\
\hline To prepare for the national examination & 89.5 & 1 & 97.3 & 1 \\
\hline To get exposure to different pedagogical methods & 87.6 & 2 & 92.0 & 2 \\
\hline To increase the amount of instructional time I get & 82.9 & 3 & 87.1 & 4 \\
\hline To prepare for university & 77.9 & 4 & 87.4 & 3 \\
\hline To experience class sizes smaller than government & 68.6 & 6 & 75.9 & 5 \\
\hline
\end{tabular}




\begin{tabular}{|l|l|l|l|l|}
\hline ones & & & & \\
\hline To satisfy demands from my parents & 72.7 & 5 & 63.5 & 6 \\
\hline To satisfy demands from my teacher & 31.8 & 7 & 24.5 & 8 \\
\hline To supplement my teacher's income & 29.8 & 8 & 24.9 & 7 \\
\hline
\end{tabular}

* The $\%$ of students who agreed or strongly agreed with this reason among students who responded to this question. $\dagger$ Ranking of importance, with 1 meaning most important, and 8 least important.

The third reason given by Grade 12 students, preparing for university, overlapped with the others. It was also a factor for Grade 9 students, but was slightly lower in their priority list because they were not yet poised to enter this stage. Rather, for Grade 9 students a more important (overlapping) reason was to increase the amount of instructional time. This factor was also important to the Grade 12 students. Three schools operated in double shifts, but even the single-shift schools had short school days. This matter has received some policy attention, with analysts arguing that Cambodian students receive significantly less instruction than counterparts in other systems (Sopha et al. 2015, p.14). The private classes permitted expansion of schooling hours.

Next on the list for many students was class size. In line with previous research (Brehm at al. 2012, p.23), most private tutoring classes were found to be smaller than those in mainstream schools. Patterns were not uniform, however, because class size varied greatly among the schools. The surveyed students indicated that regular classes on average had 47 students while the tutoring classes averaged 37 students. During interviews, both students and teachers reported that teachers sometimes combined two or three classes to make one large class, and that such combined classes were sometimes larger than in regular schooling, in one case reaching 100 students. Factors shaping the teachers' decisions included not only efficiency in operation and ability to maximise revenue but also timetabling. One interviewee explained a need to concentrate private lessons into specific time slots to avoid conflict with regular lessons for available classrooms in a double-shift school.

Another reason why students wanted smaller classes related to discipline. Students commonly indicated that classmates in large classes, especially those sitting at the back, were noisy and even talked on mobile phones and ate. Teachers similarly felt that discipline was better in smaller classes. Linking back to pedagogy, teachers added that in smaller classes they could more easily use recommended student-centred approaches. Yet even some teachers perceived large classes in regular schooling to provide the benefit that the teachers could recruit more students for private lessons.

\section{Treating Students as Customers}

The theme of treating students as customers emerged from the student data without specific questions in the interview guide. The theme included the students' perceptions of teachers' recruitment strategies to the private classes. Indirect marketing included teaching content in the private class ahead of the regular class, which meant that tutored students performed better than their peers. The students felt that in this way teachers indirectly attracted students to tutoring. One who was not receiving tutoring commented that the teacher: 
usually teaches the lesson at private tutoring before the state school, then when teaching the same lesson in the government class, the teacher calls upon the students from private tutoring to solve the problems because the students who do not attend private tutoring don't know how to solve all the problems.

Granting higher marks to tutored students was considered another form of indirect marketing:

Students who study in the extra lessons ... will get higher scores than the students who don't study in the extra lessons. Teachers will add more scores to the students who study in the extra lessons.

Other student and teacher interviewees mentioned direct marketing in which teachers publicly announced the availability of their private classes. As expressed by one, "the teachers say that if you want to be clear, you can go to my private tutoring class". Such announcements discouraged students from raising questions during regular lessons.

\section{Covering the Curriculum}

Another major ingredient concerned the curriculum, which was commonly described as overloaded for the available time. The principal component of the curriculum in the minds of both students and teachers was the government-created textbook for each subject. As noted by Brehm (2015, p.117), the MoEYS sets regulations on teaching hours and determines what students must learn within the time allocated to each subject. Many teachers then divide the textbook content by the time available to determine the learning schedule. Among the 41 students who reported on this topic, 17 stated that teachers usually were unable to finish the curriculum (or textbook) during the semester. Another 15 students stated that teachers could finish the curriculum, while nine students provided mixed responses reflecting more nuanced realities: some teachers could finish the curriculum but others could not, or sometimes teachers could finish some lessons but not others. Echoing these responses, about half of the teachers reported that they could not usually finish the curriculum.

Yet the fact that some teachers could and did complete the curriculum suggests that it was not necessarily overloaded but rather that the content was sometimes delivered inefficiently. In line with the remarks by Benveniste et al. (2008, pp.66-71), one student explained that: "The teachers are frequently absent. They come once or twice a week." Sometimes the teachers were sick, but a more significant reason was that teachers had second jobs. Teachers corroborated this information. One stated that "we don't finish the lesson on time because we are often absent". Another indicated that the authorities were lenient:

The MoEYS forgives the teachers who are absent because they understand that the teachers need to earn supplementary money to support their families.

This teacher indicated that the Ministry was anxious to retain teachers in the profession, and therefore allowed them to earn extra incomes.

With Dawson's (2009, p.65) remarks in mind about the 'tricks of the teacher' in deliberately withholding content during regular lessons in order to complete it during tutoring, 44 of the 48 interviewed 
students were asked whether they perceived the curriculum to be split between regular schooling and private tutoring. The majority $(88.6 \%)$ replied that they did not perceive a split, but five $(11.4 \%)$ replied that their teachers used private tutoring class to finish the curriculum from regular schooling. One student stated that "sometimes [the teachers] have taken the lesson to finish in the private tutoring class", while another indicated that it only happened with the exercises and not the lessons. Teachers also recognised that this happened, and tended to be defensive. Most teachers (16 interviewees) categorically denied that they ever split the curriculum, but four indicated that they had done so at some time. They explained that there was insufficient time to finish during regular lessons, so they "had to". One teacher who also had a supervisory role, remarked that some teachers "say OK that's enough: ... wait and take it to finish in private tutoring class". The interviewee indicated that it occurred in his school, and added "I say this honestly, because I am a team leader, and we see this". The implication is that students who do not receive the supplementary lessons do not receive the full curriculum (see Brehm \& Silova 2014, p.94).

\section{Demographic and Institutional Variations}

Private tutoring was not provided by every teacher. Among reasons why teachers did not provide tutoring were that they had alternative ways of generating greater incomes, that they taught subjects which were not in high demand, and that they had other commitments such as family responsibilities. A more nuanced picture takes account of these variations.

According to the teacher questionnaire data (Table 4), females were less likely to provide tutoring than males, a higher percentage of Grade 9 teachers than Grade 12 teachers did not provide tutoring, and $70.0 \%$ of teachers in single-shift schools chose not to provide tutoring compared with $38.5 \%$ in double-shift schools. These figures on single/double shift overlapped with location, since single-shift schools were in rural areas where teachers were less likely to provide tutoring. Tutoring was also less offered by younger teachers a fact that correlated with the proportions by years of teaching experience.

Table 4: Teachers who did not Provide Private Tutoring

\begin{tabular}{|l|l|c|c|c|}
\hline \multicolumn{2}{|c|}{} & $\begin{array}{c}\text { Sampled } \\
\text { teachers }\end{array}$ & $\begin{array}{c}\text { Teachers not } \\
\text { providing tutoring }\end{array}$ & $\begin{array}{c}\text { \% not providing } \\
\text { tutoring. }\end{array}$ \\
\hline \multirow{3}{*}{ Gender } & Female & 30 & 18 & 60.0 \\
\cline { 2 - 5 } & Male & 42 & 16 & 38.1 \\
\hline \multirow{3}{*}{ Grade } & Grade 9 & 43 & 24 & 55.8 \\
\cline { 2 - 5 } & Grade 12 & 29 & 10 & 34.5 \\
\hline \multirow{3}{*}{ School shift } & Double & 52 & 20 & 38.5 \\
\cline { 2 - 5 } & Single & 20 & 14 & 70.0 \\
\hline \multirow{3}{*}{ School location } & Rural & 48 & 28 & 58.3 \\
\cline { 2 - 5 } & Urban & 24 & 6 & 25.0 \\
\hline \multirow{2}{*}{$\begin{array}{l}\text { Age } \\
\text { Teaching } \\
\text { experience }\end{array}$} & $>=30$ & 54 & 24 & 44.4 \\
\cline { 2 - 5 } & $<30$ & 15 & 9 & 60.0 \\
\cline { 2 - 5 } & Five years or less & 14 & 8 & 57.1 \\
\cline { 2 - 5 } & Over five years & 56 & 14 & 25.0 \\
\hline
\end{tabular}


Note: Three teachers did not indicate their ages, and two teachers did not indicate their years of experience. Rural schools include schools in semi-urban, rural and remote locations.

A further factor concerned institutional climate and particularly the attitudes of the school principals. Among the 61 teachers who answered this part of the questionnaire, 23.0\% indicated that their principals tolerated private supplementary tutoring, while $72.1 \%$ indicated that their principals encouraged or even required it. Only $4.9 \%$ of respondents indicated that their principals had negative orientations toward the practice. During interviews, teachers reported that principals tolerated private tutoring on school premises because they considered the teachers' economic situation. For example, when talking about regulations one teacher commented: "The school principal allows us to tutor [in school]. My principal understands the living conditions of the teachers."

Additional reasons why principals might view private tutoring positively include the opportunities for students to learn more content. Some principals also had an economic motive for their schools. In most cases classrooms were provided free of charge for tutoring, but teachers in three of the six schools made donations to the schools typically of 20,000 riels (US\$5) per month. One Vice-Principal emphasised the voluntary nature of donations, explaining that "the school does not force teachers to pay, ... and they do not pay regularly", though other cases may have had a more transactional nature. This Vice-Principal added that such donations benefited the school, contributing to its infrastructure and students' activities. The donations acted like a low rent for tutoring on school premises, and had mutual benefit for the teachers and the institution.

\section{Conclusions}

This paper has focused on a form of privatisation that pervades the public system of education in Cambodia. The official façade is of a fee-free public system; but behind the façade are many fees, among which are ones for private supplementary classes delivered by teachers either to their own students or to the students of colleagues, and commonly on school premises. This practice is longstanding, but has not been the focus of adequate research. The present paper goes beyond existing literature, with questionnaire and interview data from both students and teachers in a sample of schools from a range of contexts. The paper does not claim statistical representation, and the schools are only in one province. Nevertheless, it seems likely that comparable patterns could be found elsewhere in the country.

Returning to the work of Ball and Youdell (2008) and their distinction between 'endogenous' and exogenous privatization, the patterns described in this paper could be called endogenous but are not part of the business-oriented model that Ball and Youdell presented in this category. Brehm (2015, p.36) called them "a private means of knowledge production" in which teachers utilise their expertise and positions to supplement their salaries. The paper has particularly focused on forces at the school level, in contrast to patterns in the country as a whole. Teachers have undertaken private tutoring on their own initiative, certainly to generate incomes for personal use but not as businesses in the way that Ball and Youdell had in mind. 
The question then concerns government attitudes towards these practices. At an official level, the government is critical of such fee-charging tutoring provided by teachers, especially when it is to the students for whom the teachers are already responsible in regular lessons. In this light, the next question is why the government tolerates the practice. One major component of the answer is that society generally tolerates it, and the practice enables the government to maintain salaries at a low level. Teaching still does not attract the brightest and best applicants (Tandon \& Fukao 2015; Williams et al. 2012); but, as remarked by one interviewee, the fact that teachers are permitted to earn extra incomes through tutoring and in other ways does help to retain some personnel who would otherwise leave the profession.

Figure 2 takes this matter further, showing that the government's underfunding of the education system leads to the privatisation and marketisation at the school level, but also that the privatisation and marketisation at the school level permits continued underfunding by the government. Within the schools is a cycle through which teachers use their power in classrooms to extract resources from students and their families, while the schools tolerate or even actively encourage the practice in order to gain resources for classrooms, laboratories etc. and to reduce the likelihood that teachers would leave the profession (or those specific institutions) because of inadequate salaries.

Figure 2: Privatisation and Marketisation within Schools via Transformation of Infrastructural, Financial and Human Resources

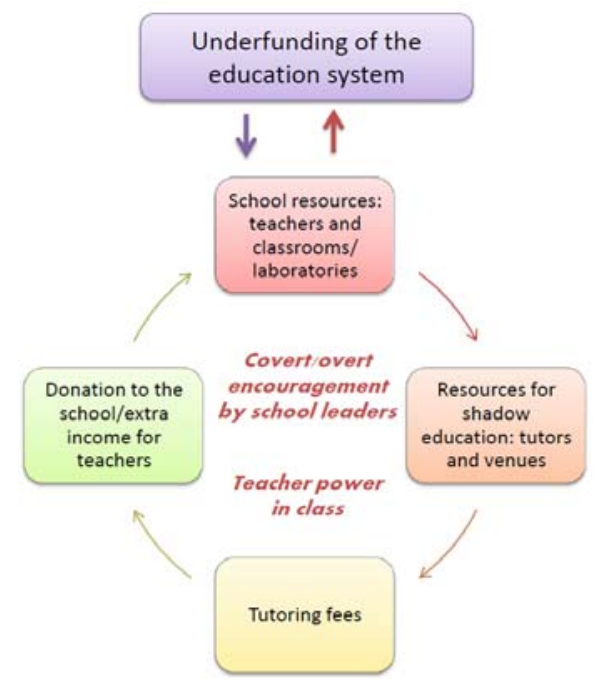

Yet while the practice allows the system to function, it has many problematic sides among which the most obvious is discrimination against students who cannot afford the private lessons and whose families may even go into debt in order to secure the full curriculum that would otherwise be denied. Both student and teacher interviewees indicated that some teachers permit lower charges for some children, or even allow them to attend the private classes free of charge; but children unable to pay the fees are still inevitably disadvantaged. A further problem relates to the values imparted by the processes which arguably involve elements of corruption. While the case studies did not indicate widespread deliberate withholding of 
curriculum material described by Dawson (2009) as among the 'tricks of the teacher', shades of the practice were evident. When such values are imparted to youth during their schooling, they are likely to persist into adulthood and have further ramifications. The UNDP has similarly remarked (2014, p.iv) that students' involvement in monetary transactions with teachers "exposes them directly to the expectation of informal payments to those in authority". The system of private payments obstructs the development of trust in public institutions.

The paper has also shown ways in which multiple components combine to shape shadow education demand and supply. While the starting point is the feeling of teachers that their salaries are inadequate and that they must somehow supplement them, other components include a curriculum that some respondents consider overloaded even though evidently some teachers can cover it within the time available, teacher absenteeism, and disciplinary problems in large classes. These factors indicate some avenues for government intervention should the authorities decide to take the matter seriously. In addition to raising teachers' salaries to remove excuses, school managers could be instructed to be less tolerant of teacher absenteeism, and further efforts could be embarked upon to limit class size. Teachers could be prohibited in particular from tutoring their own students, and they might be prohibited from providing lessons on school premises. These would be local measures to ameliorate the deficiencies of the nationally-designed system.

However, analysis must avoid simplistic presentation of solutions. First, experience elsewhere shows that once private tutoring gets into the culture it is very difficult to eradicate. This observation fits wider theories of social constructivism that show how wider forces shape the values and activities of individuals (Hall \& Taylor 1996; Jepperson 2002). The teachers in this survey were asked: "If the government decided to raise salaries on the condition that teachers no longer charged fees for private tutoring, what amount would salaries have to reach in order for you to comply?" Answers naturally varied for this hypothetical and subjective question, but averaged three times the teachers' current salaries which would clearly be beyond the government budget. In any case, patterns elsewhere show that teachers commonly provide tutoring even in relatively well-remunerated societies such as Dubai (Naismith 2014). Further, the culture of private tutoring reflects demand from parents as well as supply by teachers. When parents have adequate incomes and perceive that tutoring can assist their children in a competitive environment, then they are likely to continue to demand it even if the government frowns on the practice.

Related remarks apply to use of school premises for the tutoring. At one stage the Government of Mauritius prohibited teachers from providing tutoring on school premises but then found that much tutoring was provided in inappropriate locations including teachers' garages (Bray 2009, p.57). The Mauritian authorities therefore again decided to permit classrooms to be used, which not only provided a more suitable environment but also reduced the costs of the activity and thereby allowed prices to be lower and less discriminatory. Stakeholders in Cambodia might similarly argue that tutoring in school classrooms is preferable to tutoring in the sorts of external premises in which it would take place if tutoring in schools were prohibited. 
The reference to Mauritius indicates that this paper also fits within the broader literature on shadow education not only in Cambodia and its neighbours but also further afield. Teachers are significant actors in the shadow education marketplace not only in such Asian countries as Bangladesh, India, Maldives, Malaysia and Vietnam (see e.g. Hamid et al. 2009; Mariya 2012; Sujatha 2014), but also in parts of Africa (e.g. Maithya \& Mutua 2015) and Europe (e.g. Jokić 2013; Kobakhidze 2014; Popa \& Acedo 2006). Understanding of links between variables presented in this Cambodian case may assist researchers to undertake more sophisticated analysis in other settings.

Acknowledgements: The research reported in this chapter was funded by the General Research Fund (GRF) of the Hong Kong Research Grants Council (RGC), project 747113H. The authors also express appreciation to the TLC team and to the schools that provided information.

\section{References}

Abadzi, Helen (2007): Absenteeism and Beyond: Instructional Time Loss and Consequences. Policy Research Working Paper 4376, Washington DC: The World Bank.

Apple, Michael W. (2006): Educating the "Right" Way: Markets, Standards, God, and Inequality. $2^{\text {nd }}$ edition. New York: Routledge.

Asian Development Bank (1996): Cambodia: Education Sector Strategy Study. Manila: Asian Development Bank.

Asian Development Bank (2014): Cambodia: Country Poverty Analysis 2014. Mandaluyong City: Asian Development Bank.

Aurini, Janice; Davies, Scott \& Dierkes, Julian (eds.) (2013): Out of the Shadows: The Global Intensification of Supplementary Education. Bingley: Emerald.

Ball, Stephen J. (2012): Global Education Inc.: New Policy Networks and the Neo-Liberal Imaginary. New York: Routledge.

Ball, Stephen J. \& Youdell, Deborah (2008): Hidden Privatisation in Public Education. Brussels: Education International.

Benveniste, Luis; Marshall, Jeffery \& Araujo, M. Caridad (2008): Teaching in Cambodia. Washington DC: Human Development Sector, East Asia and Pacific Region, The World Bank.

Bray, Mark (1999): The Private Costs of Public Schooling: Household and Community Financing of Primary Education in Cambodia. Paris: UNESCO International Institute for Educational Planning (IIEP) in collaboration with UNICEF.

Bray, Mark (2009): Confronting the Shadow Education System: What Government Policies for What Private Tutoring? Paris: UNESCO International Institute for Educational Planning (IIEP).

Bray, Mark \& Bunly, Seng (2005): Balancing the Books: Household Financing of Basic Education in Cambodia. Hong Kong: Comparative Education Research Centre, The University of Hong Kong and Washington DC: The World Bank.

Bray, Mark \& Lykins, Chad (2012): Shadow Education: Private Supplementary Tutoring and its Implications for Policy Makers in Asia. Mandaluyong City: Asian Development Bank and Hong Kong: Comparative Education Research Centre, The University of Hong Kong.

Bray, Mark; Zhang, Wei; Kobakhidze, Magda Nutsa \& Liu, Junyan (2015): 'Researching Private Supplementary Tutoring in Cambodia: Contexts, Instruments and Approaches', in Bray, Mark; Kwo, Ora \& Jokić, Boris (eds.), Researching Private Supplementary Tutoring: Methodological Lessons from Diverse Cultures. Hong Kong: Comparative Education Research Centre, The University of Hong Kong, 
and Dordrecht: Springer, pp.219-244.

Brehm, William (2015): Enacting Educational Spaces: A Landscape Portrait of Privatization in Cambodia. $\mathrm{PhD}$ thesis, The University of Hong Kong.

Brehm, William C. \& Silova, Iveta (2014): 'Hidden Privatization of Public Education in Cambodia: Equity Implications of Private Tutoring'. Journal for Educational Research Online, Vol.6, No.1, pp.94-116.

Brehm, William C.; Silova, Iveta \& Tuot, Mono (2012): The Public-Private Education System in Cambodia: The Impact and Implications of Complementary Tutoring. Budapest: Education Support Program, Open Society Foundations.

Burch, Patricia (2009): Hidden Markets: The New Education Privatization. New York: Routledge.

Cambodia, Ministry of Planning (2013): Economic Census of Cambodia 2011: Provincial Report - 17 Siem Reap Province. Phnom Penh: National Institute of Statistics, Ministry of Planning.

Cambodia, MoEYS [Ministry of Education, Youth and Sport] (2015): Education Statistics and Indicators 2014-2015. Phnom Penh: Department of Planning, MoEYS.

Chandler, David (2008): A History of Cambodia. $4^{\text {th }}$ edition, Boulder: Westview Press.

Chang, Ying-Hwa (2013): 'Academic Competition and Cram Schooling', in Yi, Chin-Chun (ed.), The Psychological Well-being of East Asian Youth. Dordrecht: Springer, pp.131-153.

Chhinh, Sitha \& Dy, Sideth S. (2009): 'Education Reform Context and Process in Cambodia', in Hirosato, Yasushi \& Kitamura, Yuto (eds.), The Political Economy of Educational Reforms and Capacity Development in Southeast Asia: Cases of Cambodia, Laos and Vietnam. Dordrecht: Springer, pp.113-129.

Dawson, Walter (2009): 'The Tricks of the Teacher: Shadow Education and Corruption in Cambodia', in Heyneman, Stephen P. (ed.), Buying Your Way into Heaven: Education and Corruption in International Perspective. Rotterdam: Sense, pp.51-74.

Engel, Jakob (2011): Rebuilding Basic Education in Cambodia: Establishing a More Effective Development Partnership. London: Overseas Development Institute.

Hall, Peter A. \& Taylor, Rosemary C.R. (1996): 'Political Science and the Three New Institutionalisms'. Political Studies, Vol.XLIV, No.5, pp.936-957.

Hamid, M. Obaidul; Sussex, Roland \& Khan, Asaduzzaman Khan (2009): 'Private Tutoring in English for Secondary School Students in Bangladesh'. TESOL Quarterly, Vol.43, No.2, pp.281-308.

Ireson, Judith \& Rushforth, Katie (2014): 'Why do Parents Employ Private Tutors for their Children? Exploring Psychological Factors that Influence Demand in England'. Journal for Educational Research Online, Vol.6, No.1, pp.12-33.

Jayachandran, Seema (2014): 'Incentives to Teach Badly: After-school Tutoring in Developing Countries'. Journal of Development Economics, Vol.108, May, pp.190-205.

Jepperson, Ronald L. (2002): 'The Development and Application of Sociological Neoinstitutionalism', in Berger, Joseph \& Zeldich, Morris (eds.), New Directions in Contemporary Sociological Theory. Lanham: Rowman \& Littlefield, pp.229-266.

Jheng, Ying-Jie (2015): 'The Influence of Private Tutoring on Middle-Class Students' Use of In-class Time in Formal Schools in Taiwan'. International Journal of Educational Development, Vol.40, No.1, pp.1-8.

Jokić, Boris (ed.) (2013): Emerging from the Shadow: A Comparative Qualitative Exploration of Private Tutoring in Eurasia. Zagreb: Network of Education Policy Centers.

Kobakhidze, Magda Nutsa (2014): 'Corruption Risks of Private Tutoring: Case of Georgia'. Asia Pacific Education Review, Vol.34, No.4, pp.455-475.

Lee, Mary; Goodman, Crystal; Dandapani, Nitara \& Kekahio, Wendy (2015): Review of International Research on Factors Underlying Teacher Absenteeism. Washington DC: National Centre for Education Evaluation and Regional Assistance, U.S. Department of Education. 
Liu, Shujie \& Onwuegbuzie, Anthony J. (2014): 'Teachers' Motivation for Entering the Teaching Profession and their Job Satisfaction: A Cross-cultural Comparison of China and Other Countries'. Learning Environments Research, Vol.17, No.1, pp.75-94.

Macpherson, Ian; Robertson, Susan \& Walford, Geoffrey (eds.) (2014): Education, Privatisation and Social Justice: Case Studies from Africa, South Asia and South East Asia. Oxford: Symposium Books.

Madhur, Srinivasa \& Rethy, Chhem (2015): 'Why Focus on Cambodia's Education and Why Now?', in Sothy, Khieng; Madhur, Srinivasa \& Rethy, Chhem (eds.), Cambodia Education 2015: Employment and Empowerment. Phnom Penh: Cambodia Development Resource Institute, pp.1-5.

Maithya, Redempta \& Mutua, Elizabeth Katile (2015): 'Teachers and Students Perception on Effect of Extra Tuition on Academic Performance in Public Secondary Schools in Machakos County, Kenya'. Journal of Educational Policy and Entrepreneurial Research, Vol.2, No.8, pp.57-66.

Majumdar, Manabi (2014): The Shadow School System and New Class Divisions in India. London: Max Weber Stiftung.

Mariya, Maryam (2012): I Don't Learn at School, so I take Tuition: An Ethnographic Study of Classroom Practices and Private Tuition Settings in the Maldives. PhD thesis, Massey University.

Mkumbo, Kitila A.K. (2012): 'Teachers' Commitment to, and Experiences of, the Teaching Profession in Tanzania: Findings of Focus Group Research'. International Education Studies, Vol.5, No.3, pp.222-227.

Naismith, Luke (2014): 'Supplementary Private Tutoring in Dubai'. Unpublished report, Dubai: Knowledge and Human Development Authority.

Naren, Kuch \& Collins, Jennifer (2004): 'All Work, No Pay: Teachers in Three Provinces deal with Low, Late Salaries'. The Cambodia Daily, 10-11 January, pp.4-5.

NGO Education Partnership (2007): The Impact of Informal School Fees on Family Expenditure. Phnom Penh: NGO Education Partnership.

Nguon, Sokcheng (2012): 'Parental Involvement and Students' Achievement in Cambodia: Focusing on Parental Resourcing of Public Schooling'. International Journal of Educational Research, Vol.53, pp.213-224.

Popa, Simona \& Acedo, Clementina (2006): 'Redefining Professionalism: Romanian Secondary Education Teachers and the Private Tutoring System'. International Journal of Educational Development, Vol.26, No.1, pp.98-110.

Pugh, Geoff; Davies, Peter \& Adnett, Nick (2006): 'Should we have Faith in Not-for-profit Providers of Schooling?'. Journal of Education Policy, Vol.21, No.1, pp.19-33.

Rogers, F. Halsey \& Vegas, Emiliana (2009): No More Cutting Class? Reducing Teacher Absence and Providing Incentives for Performance. Policy Research Working Paper 4847, Washington DC: The World Bank.

Safarzyńska, Karolina (2011): 'Socio-economic Determinants of Demand for Private Tutoring'. European Sociological Review, Vol.29, No.2, pp.139-154.

Silova, Iveta; Būdienè, Virginija \& Bray, Mark (eds.) (2006): Education in a Hidden Marketplace: Monitoring of Private Tutoring. New York: Open Society Institute.

Sopha, Ang; Anderson, Colin \& Syrom Chhum (2015): Teaching Hours in Primary Schools in Cambodia. Phnom Penh: NGO Education Partnership.

Sophonnara, Sou (1994): 'Outrage over Plan to Ban Private Lessons'. Phnom Penh Post, 23 September.

Sujatha K. (2014): 'Private Tuition in India: Trends and Issues', Revue internationale d'éducation de Sèvres, online http://ries.revues.org/3796, accessed 27 November 2015.

Tandon, Prateek \& Fukao, Tsuyoshi (2015): Educating the Next Generation: Improving Teacher Quality in Cambodia. Directions in Development, Washington DC: The World Bank. 
Tedla, Habtezghi Kidane (2003): The Implementation and Organisation of Double-shift Schooling in Eritrea. MEd dissertation, University of the Western Cape, South Africa.

UNDP (2014): Curbing Private Tutoring and Informal Fees in Cambodia's Basic Education. Phnom Penh: United Nations Development Programme (UNDP).

Ward, Stephen (2013): 'Education Policy and the Marketization of Education', in Ward, Stephen (ed.), A Student's Guide to Education Studies. New York: Routledge, pp.3-11.

Williams, James, H; Kitamura, Yuto \& Zimmermann, Thomas (2012): Privatization and Teacher Education in Cambodia: Implications for Equity. Budapest: Education Support Programme, Open Society Foundations.

Woodhead, Martin; Frost, Melanie; James, Zoe (2013): 'Does Growth in Private Schooling Contribute to Education for All? Evidence from a Longitudinal, Two Cohort Study in Andhra Pradesh, India', International Journal of Educational Development, Vol.33, No.1, pp.65-73.

Zeng, Kangmin (1999): Dragon Gate: Competitive Examinations and their Consequences. London: Cassell. 